\title{
WYJĄTKOWE DOŚWIADCZENIA PASAŻERÓW JAKO WYRÓŻNIK LINII LOTNICZYCH ${ }^{2}$
}

\begin{abstract}
W dobie gospodarki doświadczeń, której nastanie ogłoszono z końcem XX w., konkurowanie między markami odbywa się głównie w wymiarze dostarczania unikatowych doznań. Dla współczesnych klientów coraz częściej ich wyjątkowe doświadczenia, towarzyszące nabywaniu lub konsumowaniu produktów, stają się kluczową determinantą wyborów rynkowych. W literaturze przedmiotu zagadnienie marketingu doświadczeń przedstawiano w kontekście wielu obszarów aktywności gospodarczej - m.in. turystyki, handlu detalicznego, usług bankowych. Brakuje natomiast publikacji (zwłaszcza w polskim piśmiennictwie), które dotyczyłyby doświadczeń powstających podczas korzystania z usług linii lotniczych. Istnieje zatem luka badawcza, której częściowemu wypełnieniu ma służyć niniejsze opracowanie. Jego celem jest zidentyfikowanie elementów ofert, za pośrednictwem których przewoźnicy starają się wywoływać unikatowe doświadczenia pasażerów - takich, które można uznać za wyjątkowe, długo pamiętane doznania. Na potrzeby tekstu zaproponowano ujęcie kategorii „wyjątkowego doświadczenia klienta”. Zaprezentowane wnioski sformułowano w oparciu o przegląd literatury, jak również doświadczenia autora, który korzystał z usług kilkudziesięciu linii lotniczych. Egzemplifikacji dla prowadzonych rozważań dokonano na podstawie dwóch przewoźników, uznawanych za liderów w obszarze innowacji produktowych - Singapore Airlines oraz Emirates. W oparciu o rozwiązania wprowadzone przez te linie wysunięto konkluzje dotyczące znaczenia unikatowych doświadczeń na tle innych elementów ofert, stanowiących podstawę konkurowania na rynku pasażerskich przewozów lotniczych. Ponadto wskazano determinanty skutecznego wprowadzania nowych rozwiązań, pozwalających kreować wyjątkowe doznania. Do takich determinant zaliczono m.in.: planowanie z dużym wyprzedzeniem wdrażanych zmian, spójne podkreślanie kluczowych wartości marki - za pośrednictwem wielu bodźców oraz w perspektywie długoterminowej; spojrzenie na dostarczane doznania przez pryzmat całego procesu zarządzania doświadczeniem klienta.
\end{abstract}

Słowa kluczowe: marketing doświadczeń, wyjątkowe doświadczenia klienta, zarządzanie doświadczeniem klienta, marketing linii lotniczych.

\footnotetext{
${ }^{1}$ Dr hab. Marcin Gębarowski, Katedra Zarządzania Procesowego, Wydział Towaroznawstwa i Zarządzania Produktem, Uniwersytet Ekonomiczny w Krakowie; ul. Rakowicka 27, 31-510 Kraków; e-mail: marcin.gebarowski@uek.krakow.pl.

Marcin Gębarowski, DSc, Ph.D., Department of Process Management, Faculty of Commodity Science and Product Management, Cracow University of Economics; Rakowicka 27 Str., 31-510 Cracow; e-mail: marcin.gebarowski@uek.krakow.pl.

2 Publikacja sfinansowana ze środków przyznanych Wydziałowi Towaroznawstwa i Zarządzania Produktem Uniwersytetu Ekonomicznego w Krakowie w ramach dotacji na utrzymanie potencjału badawczego.
} 


\section{WPROWADZENIE}

Z roku na rok rynek pasażerskich przewozów lotniczych wzrasta - zarówno w wymiarze globalnym, jak i krajowym. Według Organizacji Międzynarodowego Lotnictwa Cywilnego (ang. International Civil Aviation Organization - ICAO) w 2017 r. osiągnięto rekordową liczbę pasażerów przetransportowanych przez linie lotnicze. Na całym świecie było to 4,1 mld osób, co stanowiło 7,1\% wzrostu w stosunku do poprzedniego roku ${ }^{3}$. W Polsce dynamika poszerzania się rynku pasażerskich przewozów lotniczych jest jeszcze większa. Z danych Urzędu Lotnictwa Cywilnego wynika, że w 2017 r. liczba pasażerów obsłużonych na krajowych lotniskach - w ruchu regularnym oraz czarterowym - wzrosła w odniesieniu do 2016 r. o 22,3\% (w 2016 r. było to 3,6 mln pasażerów, zaś w 2017 r. - 4,4 mln osób) ${ }^{4}$. Przewiduje się, że podczas dwóch najbliższych dekad trend wzrostowy utrzyma się i polskie lotniska będą obsługiwać coraz więcej podróżnych - z kilkuprocentową dynamiką wzrostu rocznie ${ }^{5}$. Rynek poszerza się w różnych segmentach nabywców usług lotniczych także i w tym segmencie, w którym pasażerowie są w stanie więcej zapłacić za bilet, oczekując w zamian zwiększonego komfortu podróży i możliwości przeżycia wyjątkowych doznań ${ }^{6}$. Świadczą o tym znaczące inwestycje wielu linii lotniczych w rozwiązania mające dostarczać niezapomnianych przeżyć. Bowiem to właśnie budowanie pozytywnego doświadczenia pasażera $w$ ramach dostarczania usługi przewozu należy zaliczyć obecnie do jednego z głównych elementów konkurowania linii lotniczych (oprócz czterech innych wymiarów rywalizacji rynkowej: zapewnienia pełnego bezpieczeństwa lotów, skrócenia czasu podróży, sprzedaży biletów lotniczych gwarantujących uzyskanie możliwie najwyższego wskaźnika wypełnienia samolotów, osiągania wyniku finansowego zadowalającego inwestorów) $)^{7}$.

Celem niniejszego artykułu jest zidentyfikowanie przejawów wzbogacania produktów linii lotniczych o elementy budujące unikatowe doznania pasażerów - takich doznań, które są długo przez nich pamiętane i decydują o ponownym wyborze marki przewoźnika. Zaprezentowane wnioski sformułowano na podstawie przeglądu literatury, jak również doświadczeń autora, który korzystał z usług blisko trzydziestu linii lotniczych. Artykuł ujmuje podjęte zagadnienie w wymiarze teoretycznym - wskazując przede wszystkim obszary kreowania unikatowych doświadczeń przez linie lotnicze, co może stanowić podstawę realizowania przyszłych badań wśród pasażerów.

Przedmiotem zainteresowania w opracowaniu jest oferta podmiotów będących regularnymi liniami lotniczymi, które - w odróżnieniu od przewoźników niskobudżetowych (low

${ }^{3}$ Continued passenger traffic growth and robust air cargo demand in 2017, https://www.icao. int/Newsroom/Pages/Continued-passenger-traffic-growth-and-robust-air-cargo-demand-in-2017. aspx (dostęp: 7.05.2018 r.).

${ }^{4}$ Liczba obstużonych pasażerów oraz wykonanych operacji $w$ ruchu krajowym - regularnym i czarterowym w latach 2015-2017, http://www.ulc.gov.pl/_download/statystyki/2017/wg_portow_krajowe_4kw2017.pdf (dostęp: 7.05.2018 r.).

5 Projekcja liczby obstużonych pasażerów oraz liczby operacji pasażerskich w Polsce do roku 2035, http://www.ulc.gov.pl/_download/regulacja_rynku/statystyki/prognozy/prognoza_2017.pdf (dostęp: 7.05.2018 r.).

${ }^{6}$ W niniejszym opracowaniu pojęcia ,doświadczenie” oraz ,doznanie” traktowane są synonimicznie.

${ }^{7}$ D. Rucińska, J. Kotarbiński, Wspótczesne modele komunikacji marketingowej przewoźników lotniczych [w:] Europejski transport i rynek ustug transportowych, red. D. Rucińska, Zeszyty Naukowe Uniwersytetu Gdańskiego, „Ekonomika Transportu i Logistyka” 2014, 52, s. 54. 
cost) - nie skupiają się wyłącznie na konkurowaniu ceną biletów. Regularne linie lotnicze oferują bowiem kompleksową usługę, na którą składają się przede wszystkim: bardziej zróżnicowane klasy rezerwacyjne, wyższy standard podróży (np. więcej miejsca na nogi w klasie ekonomicznej), bezpłatne nadanie bagażu rejestrowanego, darmowe posiłki podczas lotu, większe prawa dotyczące modyfikacji czy anulowania rezerwacji, wystawienie jednego biletu dla podróży obejmujące loty samolotami kilku zrzeszonych linii.

Przez większość pasażerów wszystkie linie lotnicze postrzegane są niemal tak samo i nie widzą oni istotnych powodów, aby wybrać konkretną z nich. Istnieje jednak kilku przewoźników, którzy zdołali zbudować wyróżniającą się markę - głównie za sprawą wyprzedzania swoich konkurentów w wymiarze dostarczania wyjątkowych doświadczeń pasażerom. Przykładami są linie Singapore Airlines oraz Emirates ${ }^{8}$. To właśnie w odniesieniu do tych linii dokonano egzemplifikacji dla rozważań prowadzonych w tym tekście.

Zagadnienie dostarczania wyjątkowych doświadczeń klientom linii lotniczych nie zostało jeszcze wystarczająco opisane w literaturze naukowej. O ile istnieją pojedyncze publikacje zagranicznych autorów poświęcone tej tematyce ${ }^{9}$, o tyle krajowe piśmiennictwo z zakresu marketingu doświadczeń nie obejmuje pozycji odnoszących się do lotniczych przewozów pasażerskich. Niniejsze opracowanie wypełnia zatem częściowo istniejącą lukę badawczą.

\section{KATEGORIA „WYJATTKOWEGO DOŚWIADCZENIA”}

Dwie dekady temu B.J. Pine i J.H. Gilmore ogłosili nastanie ery gospodarki doświadczeń (experience economy) ${ }^{10}$. Od tego momentu zaczęto przykładać dużą wagę do doznań klientów oraz ich roli w uzyskiwaniu przewagi rynkowej. Niemal w tym samym czasie pojawiła się pierwsza publikacja posługująca się kategorią „wyjątkowe doświadczenie” (extraordinary experience $)^{11}$. Z czasem opublikowano kolejne prace naukowe, w których główny przedmiot rozważań stanowiły ponadprzeciętne doznania ${ }^{12}$.

$\mathrm{W}$ piśmiennictwie z zakresu marketingu nie ma klarownego, powszechnie akceptowanego ujęcia, precyzującego, które doświadczenia klientów można postrzegać jako wyjątkowe. Jednak, w oparciu o zaproponowane dotąd podejścia, za wyjątkowe (extraordinary) - w przeciwieństwie do zwykłych doznań (ordinary) - należy uznać te, które w lite-

${ }^{8}$ Por. S. Shaw, Airline Marketing and Management, Ashgate, Aldershot 2007, s. 107.

9 Por. m.in.: J.L. Le Bel, Beyond the friendly skies: an integrative framework for managing the air travel experience, ,Managing Service Quality: An International Journal” 2005, 15/5, s. 437-451; C. Laming, K. Mason, Customer experience - an analysis of the concept and its performance in airline brands, „Research in Transportation Business \& Management” 2014, 10, s. 15-25; R.Z. Rizvi, Analysis of the dimensions of customer experience with reference to Indigo Airlines and Jest Airways, „Business Sciences International Research Journal” 2016, 4, s. 16-19.

10 B.J. Pine, J.H. Gilmore, Welcome to the Experience Economy, „Harvard Business Review” 1998, 76/4, s. 97-105.

${ }^{11}$ E.J. Arnould, L.L. Price, River Magic: Extraordinary Experience and the Extended Service Encounter, ,Journal of Consumer Research” 1993, 20/1, s. 24-45.

12 Por. L. Mossberg, Extraordinary Experiences through Storytelling, „Scandinavian Journal of Hospitality and Tourism" 2008, 8/3, s. 195-210; A. Bhattacharjee, C. Mogilner, Happiness from Ordinary and Extraordinary Experiences, ,,Journal of Consumer Research” 2014, Vol. 41/1, s. 1-17; G. Cooney, D.T. Gilbert, T.D. Wilson, The Unforeseen Costs of Extraordinary Experience, „Psychological Science” 2014, 25/12, s. 2259-2265. 
raturze przedmiotu określa się jako znaczące (meaningful) ${ }^{13}$ lub godne zapamiętania (memorable $)^{14}$. Doświadczenia zwykłe pojawiają się niejako „rutynowo”, będąc częścią codziennego życia klientów. Dotyczą one przeszłości i stanowią efekt biernej akceptacji różnych wydarzeń ${ }^{15}$. Z kolei doświadczenia znaczące, zapadające w pamięć - zatem mogące zostać uznane za wyjątkowe - mają głębsze podłoże. Powstają one w następstwie znalezienia się człowieka w nowych dla niego, nieznanych sytuacjach, którym towarzyszy intensywność emocjonalna ${ }^{16}$. Mogą być to także sytuacje już znane (np. kolejny lot tymi samymi liniami), jednak mające miejsce w na tyle osobliwym otoczeniu, że powstającym wrażeniom towarzyszy duża intensywność.

Na potrzeby niniejszego opracowania proponuje się przyjąć, że wyjątkowe doświadczenia wywoływane są za sprawą znalezienia się klienta w nietypowej (innej niż zwykła, rzadkiej) dla niego sytuacji, w rezultacie czego powstają silne przeżycia, zapadające na długo w pamięć. Takimi sytuacjami mogą być np.: zaoferowanie oryginalnego posiłku w samolocie, wyjątkowa troska personelu pokładowego o pasażera lub stworzenie ponadprzeciętnie komfortowych warunków podróżowania.

\section{WYJĄTKOWE DOŚWIADCZENIA W OFERTACH LINII LOTNICZYCH}

Sektor usług, w tym również usług oferowanych przez przewoźników na rynku pasażerskich przewozów lotniczych, jest nierozerwalnie związany z doświadczeniami klientów. Często nawet samo doznanie bywa identyfikowane $\mathrm{z}$ usługą - ze względu na to, że spełnia podstawowe kryteria niematerialności, niejednorodności, niemożliwości magazynowania czy nietrwałości ${ }^{17}$. Dla niektórych osób marka usługi jest wręcz synonimem doświadczenia $^{18}$. Występują jednak istotne różnice między usługą a doznaniem. Usługa wykonywana jest dla klienta i dotyczyć może jego ciała (np. manicure), własności (m.in. umycie samochodu) lub określonego zadania (np. wykonanie rozliczenia z urzędem skarbowym). Tymczasem doświadczenie wywiera wpływ na klienta, robi mu coś (np. przez rozrywkę) i sprawia, że pozostaje mu wspomnienie. Zarówno w przypadku towarów, usług, jak i doświadczeń występuje faza konsumpcji, przy czym w przypadku doznań konsumpcja jest głównym elementem oferty. Podczas, gdy towary są materialne i można je faktycznie posiadać, usługi są niematerialne, ale pozostawiają klienta z jakimś efektem, będącym następstwem procesu ich świadczenia. Przy doświadczeniach liczy się tylko to, co zachodzi między adresatem działań marketingowych a przedsiębiorstwem w rozszerzonej i zintensyfikowanej fazie konsumpcji oraz pozostałe po tym na długo wspomnienia ${ }^{19}$. Warto przy

${ }^{13}$ I. Riivits-Arkonsuo, A. Leppiman, Consumer Journey from First Experience to Brand Evangelism, „Research in Economics and Business: Central and Eastern Europe” 2014, 6/1, s. 6.

${ }^{14} \mathrm{Ph}$. Kotler, Marketing Insights from A to Z, John Wiley \& Sons, Hoboken 2003, s. 62.

15 A. Carù, B. Cova, Revisiting Consumption Experience: A More Humble but Complete View of the Concept, ,Marketing Theory” 2003, 3/2, s. 275.

16 Por. E.J. Arnould, L.L. Price, River Magic: Extraordinary..., s. 25.

17 A. Kacprzak, K. Dziewanowska, M. Skorek, Gospodarka doświadczeń. Perspektywa polskiego konsumenta, Warszawa 2016, s. 44.

${ }^{18}$ M. Boguszewicz-Kreft, Marketing doświadczeń. Jak poruszać zmysty, zaangażować emocje, zdobyć lojalność klientów?, Warszawa 2013, s. 49.

19 A. Kacprzak, K. Dziewanowska, M. Skorek, Gospodarka doświadczeń..., s. 44-45. 
tym wspomnieć, że doznania budowane przez firmy usługowe są na ogół znacznie bardziej kompleksowe niż doświadczenia przedsiębiorstw wytwarzających dobra materialne ${ }^{20}$.

Doznania klientów, odnoszące się do danej organizacji (np. linii lotniczej), tworzy wiele oddzielnych zdarzeń (incydentów), i organizacja powinna mieć ich całościowy obraz, patrząc na te zdarzenia z perspektywy klientów ${ }^{21}$. Dostarczanie pożądanych wrażeń nabywcom usług, w tym również pasażerom podróżującymi samolotami, wymaga zatem zastosowania kompleksowego podejścia, jakiem jest zarządzanie doświadczeniem klienta (Customer Experience Management - CEM). Ta koncepcja w dużej mierze opiera się na tzw. punktach styku (touch points). Punkty te są chwilami w procesie świadczenia usług, w których następuje bezpośredni lub pośredni kontakt klienta z marką, a tym samym powstają doświadczenia. Podróż samolotem może zostać ujęta w postaci takich punktów styku, stanowiących momenty prawdy (moments of truth) dla konkretnej linii lotniczej22. Niektóre z tych momentów są dla klienta pozytywne, a inne negatywne (rys. 1). Przy czym można

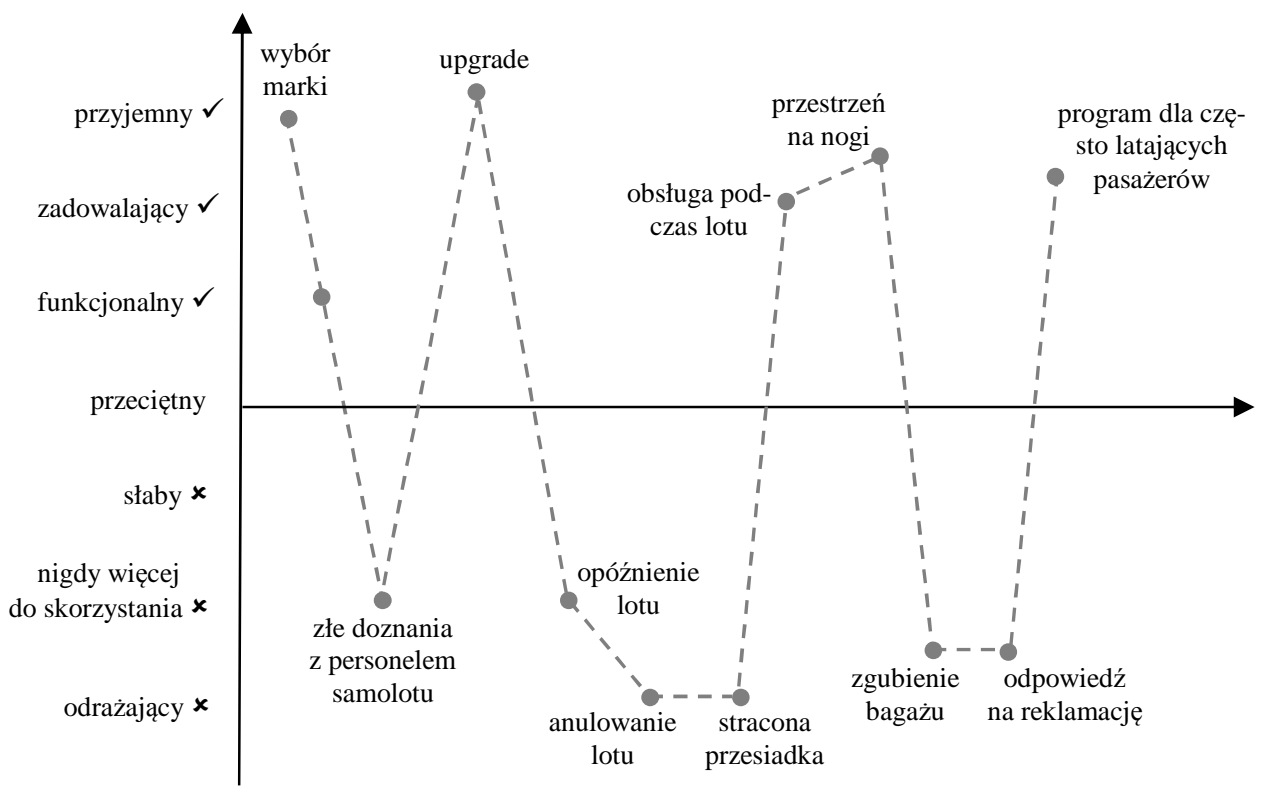

Rys. 1. Ocena „,momentów prawdy” podczas korzystania z usług linii lotniczych

Źródło: P.R. Gamble, A. Tapp, A. Marsella, M. Stone, Marketing Revolution: The Radical New Approach to Transforming the Business, the Brand, and the Bottom Line, London-Sterling 2007, s. 59.

${ }^{20}$ M. Boguszewicz-Kreft, Marketing doświadczeń..., s. 61.

${ }^{21}$ S. Baron, K. Harris, Services Marketing. Text and Cases, New York 2003, s. 195.

${ }^{22}$ Momenty prawdy są tymi chwilami w doświadczeniach klientów, które szczególnie mocno wpływają na ocenę przez nich wartości, jaką otrzymują. Weryfikują one istniejące oczekiwania klientów - pozytywnie lub pejoratywnie. Momenty prawdy, jako najważniejsze składniki doświadczeń klientów, mają miejsce w punktach kontaktu, czyli wszędzie tam, gdzie klient spotyka się z marką (por. J. Pogorzelski, Momenty prawdy i punkty kontaktu, http://jacekpogorzelski.pl/ momenty-prawdy-i-punkty-kontaktu, dostęp: 10.05.2018 r.). 
założyć, że w chwili wyboru marki przewoźnika przyszły pasażer ma pozytywne nastawienie wobec niej.

Kluczowe przy planowaniu oraz tworzeniu zamierzonych doświadczeń klientów jest zrozumienie, które punkty styku są krytyczne, a następnie zarządzanie nimi w taki sposób, aby w każdym z tych punktów zapewnić doznania zwiększające satysfakcję klientów. Takie podejście można odnieść do linii lotniczych, proponując wykorzystania analizy momentów prawdy do stworzenia nowego, bardziej pozytywnie postrzeganego zestawu doświadczeń klientów (tabela 1).

Tabela 1. Tworzenie nowego doświadczenia w usłudze lotniczej

\begin{tabular}{|c|c|c|c|c|c|c|}
\hline $\begin{array}{l}\text { „Momenty } \\
\text { prawdy” }\end{array}$ & $\begin{array}{c}\text { Podróż } \\
\text { na lotnisko }\end{array}$ & Odprawa & $\begin{array}{c}\text { Komfort } \\
\text { przed lotem }\end{array}$ & $\begin{array}{c}\text { Komfort } \\
\text { podczas lotu }\end{array}$ & Przylot & $\begin{array}{c}\text { Podróż } \\
\text { do miejsca } \\
\text { przeznaczenia }\end{array}$ \\
\hline Odczucia & $\begin{array}{l}\text { - stres } \\
\text { - zamieszanie } \\
\text { - brak miejsca } \\
\text { parkingo- } \\
\text { wego } \\
\text { - noszenie } \\
\text { bagażu }\end{array}$ & $\begin{array}{l}\text { - długa, frustru- } \\
\text { jąca kolejka } \\
\text {-odprawa zby- } \\
\text { teczna (ko- } \\
\text { nieczna tylko } \\
\text { przy samolo- } \\
\text { cie) }\end{array}$ & $\begin{array}{l}\text { - chęć/potrzeba } \\
\text { popracowania } \\
\text { - chęć/potrzeba } \\
\text { relaksu }\end{array}$ & $\begin{array}{l}\text { - niski komfort } \\
\text { - długi czas } \\
\text { spędzony } \\
\text { w fotelu } \\
\text { - nuda }\end{array}$ & $\begin{array}{l}\text { - zmęczenie } \\
\text { - stan nie- } \\
\text { świeżości } \\
\text { - bałagan } \\
\text { w ubiorze }\end{array}$ & $\begin{array}{l}\text { - stanie w kor- } \\
\text { kach ulicz- } \\
\text { nych } \\
\text { - nieznane } \\
\text { miejsce }\end{array}$ \\
\hline \multicolumn{7}{|c|}{ Doświadczenie klienta } \\
\hline $\begin{array}{l}\text { Rozwiązania } \\
\text { zastosowane } \\
\text { w procesie } \\
\text { świadczenia } \\
\text { usługi }\end{array}$ & $\begin{array}{l}\text { - transport } \\
\text { na lotnisko } \\
\text { - kierowca } \\
\text { noszący } \\
\text { bagaże }\end{array}$ & $\begin{array}{l}\text { - szybka ścieżka } \\
\text { odprawy } \\
\text { - linia lotnicza } \\
\text { zna miejsce } \\
\text { przebywania } \\
\text { pasażera }\end{array}$ & $\begin{array}{l}\text { - pomieszczenie } \\
\text { z dostępem } \\
\text { do internetu, } \\
\text { biblioteką } \\
\text { - salon masażu, } \\
\text { salon kosme- } \\
\text { tyczny } \\
\text { - pokój z grami }\end{array}$ & $\begin{array}{l}\text { - rozkładane } \\
\text { fotele } \\
\text { - nastrojowe } \\
\text { oświetlenie } \\
\text { - ,symulacja } \\
\text { świtu” } \\
\text { - dania do wy- } \\
\text { boru }\end{array}$ & $\begin{array}{l}\text {-osoba asy- } \\
\text { stenta cze- } \\
\text { kająca po } \\
\text { przylocie } \\
\text { - prysznice } \\
\text { - miejsce do } \\
\text { makijażu } \\
\text { lub ogole- } \\
\text { nia się } \\
\text { - prasowanie } \\
\text { ubrań } \\
\text { - śniadanie }\end{array}$ & $\begin{array}{l}\text { - podróż } \\
\text { do miejsca } \\
\text { docelowego } \\
\text { - kierowca do- } \\
\text { brze zorien- } \\
\text { towany w lo- } \\
\text { kalnych rea- } \\
\text { liach }\end{array}$ \\
\hline
\end{tabular}

Źródło: P.R. Gamble, A. Tapp, A. Marsella, M. Stone, Marketing Revolution..., s. 61.

Zaprezentowane w tabeli podejście do tworzenia nowych doświadczeń, będące efektem analizy i zmiany odczuć powstających w ,,momentach prawdy”, można odnaleźć w działaniach zaprezentowanych w poniższych przykładach.

\section{PRZYKŁADY DOSTARCZANIA PASAŻEROM WYJĄTKOWYCH DOŚWIADCZEŃ}

Egzemplifikacja oferowania klientom unikatowych doznań dokonana zostanie w oparciu o dwie linie lotnicze - Singapore Airlines oraz Emirates. Obie - w ujęciu globalnym należą do grupy kilkunastu największych pasażerskich przewoźników lotniczych ${ }^{23}$ i po-

${ }^{23}$ M. Polkowska, Komunikacja lotnicza na świecie w XXI wieku, „Modern Management Review”, XX, $22(2 / 2015)$, s. 117. 
strzegane są jako liderzy w obszarze innowacji produktowych ${ }^{24}$. Linie konsekwentnie dążą do tego, aby stać na czele nowych osiągnięć w takich obszarach, jak komfort w kabinie, obsługa pasażera czy rozrywka na pokładzie samolotu. Zarówno singapurski, jak i emiracki przewoźnik, są przykładami podejścia do prowadzenia biznesu, które określa się w języku angielskim First Mover Advantage, co można przetłumaczyć jako ,przewaga pierwszego ruchu". Zastosowanie tego podejścia pozwala pionierowi czerpać korzyści z wprowadzonych innowacji nawet po skopiowaniu ich przez konkurencję ${ }^{25}$.

Linie Singapur Airlines słyną z wyjątkowej aparycji stewardes. Żeński personel pokładowy ubrany jest w sarongi kebaya, zaprojektowane w 1972 r. przez Pierre'a Balmain'a (znanego francuskiego projektanta mody). Uniformy wykonane są z wysokiej jakości jedwabiu, a wzory na nich nanosi się metodą batik (techniką malarską polegającą na kolejnym nakładaniu wosku i kąpielach tkaniny w barwniku, który farbuje jedynie miejsca niepokryte woskiem). Strój występuje w czterech odmianach kolorystycznych, wskazujących pozycję zajmowaną w hierarchii załóg pokładowych. Sarong z dominującym kolorem niebieskim oznacza stewardesę znajdująca się najniżej w hierarchii, z czerwonym zaś - osobę kierującą zespołem. Sylwetka kobiet powinna pasować do jednego rozmiaru stroju. Mężczyźni, członkowie załóg, noszą krawaty nawiązujące motywami oraz kolorystyką do ubioru stewardes. Wyjątkowa dbałość linii lotniczych o wygląd reprezentującego go personelu sprawiła, że w powszechnym obiegu zaczęło funkcjonować określenie Singapore Girl, a postać stewardesy przewoźnika w 1994 r. pojawiła się w londyńskim Muzeum Figur Woskowych Madame Tussaud.

Oprócz stroju, pozytywnych doświadczeń pasażerom korzystającym z usług Singapur Airlines ma dostarczać starannie wyćwiczone zachowanie personelu pokładowego. Osoby, które aplikują do pracy w singapurskich liniach i w przyszłości mają opiekować się pasażerami, przechodzą wymagającą selekcję, a następnie staranne przeszkolenie (obejmujące m.in. naukę odpowiedniego poruszania się po kabinie samolotu oraz podawania posiłków).

Singapurskie linie lotnicze od lat 90. ubiegłego wieku w przemyślany sposób oddziałują na zmysł powonienia pasażerów. Jednym z osobliwych elementów tożsamości marki Singapore Airlines jest bowiem specjalnie zaprojektowana dla niej - i objęta ochroną prawną - perfuma o nazwie Stefan Floridian Waters ${ }^{26}$. Tym egzotycznym zapachem nasiąknięte są wnętrza samolotów. Między innymi perfumami nasącza się gorące ręczniki, podawane pasażerom przed startem.

Marka Singapore Airlines - na tle wielu innych linii lotniczych - w rozszerzony sposób oddziałuje na zmysł smaku. Podczas lotów międzykontynentalnych serwowane są posiłki o wysokiej jakości, które można wybrać (spośród kilku wariantów) z menu rozdawanego przez stewardesy. Ponadto pasażerowie podróżujący pierwszą klasą, klasą biznes oraz klasą ekonomiczną Premium mogą skorzystać z opcji Book the Cook, zamawiając (do 24 godz. przed wylotem) dania od znanych kucharzy - m.in. Gordona Ramsay'a.

Wyróżnikiem Singapore Airlines stała się zwiększona dbałość o komfort pasażerów. System rozrywki pokładowej KrisWorld obejmuje tysiąc programów audiowizualnych. Ponadto zainstalowane oprogramowanie umożliwia pasażerom na przygotowanie własnych

${ }^{24}$ S. Shaw, Airline Marketing and Management..., s. 106.

5 Ibidem, s. 106

${ }^{26}$ I. Skowronek, Marketing sensoryczny a wartość dla klienta [w:] Zarzadzanie przedsiębiorstwem w pracach doktorantów, red. B. Dobiegała-Korona, Warszawa 2009, s. 216. 
dokumentów, takich jak arkusze kalkulacyjne czy prezentacje. Komfortowe warunki podróżowania zapewniają najszersze wśród przewoźników fotele oraz - w klasie biznes konfiguracja miejsc w układzie 1-2-1. Jednak przejawem skrajnej dbałości o wygodę podróżnych są apartamenty oferowane w nowych samolotach Airbus A380, dostępne w pierwszej klasie, na wybranych trasach, od końca 2017 r. W każdym nowym samolocie tego typu na górnym pokładzie znajduje się sześć odseparowanych apartamentów, zamykanych przesuwnymi drzwiami. We wnętrzach kabin umieszczono pojedyncze łóżka, szafy, skórzane fotele, duże telewizory, panele do sterowania roletami w oknach i oświetleniem, pulpity z miejscami do pracy, zestawy kosmetyków. Warto wspomnieć, iż ta inwestycja Singapore Airlines w pierwsza klasę nie jest pionierską, gdyż już w 2008 r. linie lotnicze wprowadziły Suite Class - najbardziej luksusową wówczas klasę podróżowania.

W wymiarze wyjątkowego komfortu pasażerów z dalekowschodnim przewoźnikiem konkuruje linia Emirates. Tydzień po zaprezentowaniu przez Singapore Airlines nowej oferty z apartamentami na pokładach Airbusów 380, emiracki przewoźnik przedstawił odświeżone wnętrza swoich samolotów Boeing 777, w tym prywatnych kabin dostępnych w pierwszej klasie. Emirates, informując o swoim nowym elemencie produktu, powoływał się na współpracę w projektantami Mercedes-Benz i inspirowanie wystroju apartamentów samochodami tej marki z wariantu S-Class. We wnętrzach kabin dominuje kolorystyka szaro-kremowa, zamontowano fotele z obiciami z miękkiej skóry oraz oświetlenie ambientowe (pasażerowie mogą regulować barwę światła). Na wyposażaniu luksusowych kabin znalazły się ponadto: duże telewizory, panele sterowania z ekranami dotykowymi, nawilżające pidżamy, lornetki do obserwowania widoków za oknem samolotu. Innowacją technologiczną jest możliwość zdalnego prowadzenia rozmów wideo z personelem pokładowym. Ponadto, w kabinach usytuowanych w środkowym rzędzie, Emirates - jako pierwszy na świecie - zainstalował wirtualne okna. Dzięki tej technologii można obserwować w rozdzielczości HD widoki za oknem, gdyż urządzania w czasie rzeczywistym transmitują obraz z kamer zlokalizowanych na zewnątrz samolotu. Pasażerowie pierwszej klasy mogą również wziąć prysznic na pokładzie, a do ich dyspozycji są ekskluzywne kosmetyki marki Bulgari. Dopełnieniem oferty z apartamentami stanowi transport pasażerów pierwszej klasy z wybranego miejsca w Dubaju na lotnisko i z lotniska luksusowymi limuzynami Mercedes-Benz z własnym szoferem. Warto wspomnieć, że podobna usługa - jednak dowozu innymi markami samochodów - oferowana jest przez bliskowschodniego przewoźnika w 70 innych miastach (w tym również w Warszawie, do $40 \mathrm{~km}$ od lotniska Chopina) pasażerom klasy pierwszej oraz klasy biznes.

Emirates, oprócz zmian w aranżacji apartamentów, w klasie biznesowej zainstalowały skórzane fotele rozkładane do całkowicie leżącej pozycji, wyposażone w podręczny barek. Z kolei w klasie ekonomicznej umieszczono siedziska z regulowanymi zagłówkami z naturalnej skóry. Ponadto zmieniono ogólną kolorystykę samolotów, aranżując ich wnętrza w barwach jasnoszarej i niebieskiej.

Ubiór stewardes należy do jednych z najbardziej charakterystycznych spośród personelu pokładowego wszystkich linii lotniczych. Przez wielu pasażerów to przede wszystkim te uniformy są kojarzone z liniami Emirates. Kobiecy strój stanowią garsonki i spódnice w kolorze khaki, jak również czerwone czapki, przypominające toczek, z białym welonem. Welon przytrzymuje krążek imitujący agal (tradycyjne arabskie nakrycie głowy). Mężczyźni, reprezentujący przewoźnika, noszą brązowe garnitury, kremowe koszule i brązowo-czerwone krawaty. Stroje zostały zaprojektowane przez brytyjski dom mody Simon Jersey. 
Emirates - podobnie, jak Singapore Airlines - wymagają od stewardes ścisłego przestrzegania wytycznych dotyczących makijażu, koloru lakieru do paznokci oraz ułożenia włosów. W ramach załóg pokładowych emirackiego przewoźnika pracują osoby z ponad 160 państw, w tym również liczny personel z Polski.

Linie Emirates serwują podczas lotów - za dodatkową opłatą - tort i szampana (takie zamówienie można złożyć do 24 godz. przed wylotem), aby np. celebrować uroczystość współpasażera. Menu przewoźnika jest ponadprzeciętnie dla branży zróżnicowane, z listą uznanych na świecie win. Spis dań uwzględnia zalecenia medyczne pasażerów oraz ich przekonania religijne, jak również zawiera specjalne posiłki dla dzieci. Linie z Bliskiego Wschodu - jako jedyne na świecie - oferują jedzenie z wszystkich regionów, do których latają (np. z Australii i Nowej Zelandia). W klasie biznes pasażer ma do wyboru szeroki wybór posiłków serwowanych na porcelanie Royal Doulton z kompletem sztućców Robert Welch, zaprojektowanych specjalnie dla tych linii lotniczych. Unikatowa jest także herbata Emirates Signature Tea, podawana pasażerom pierwszej klasy, będąca mieszanką stworzoną przez markę Dilmah na zamówienie przewoźnika.

Emirates były pierwszymi liniami, które wprowadziły indywidualne ekrany telewizyjne we wszystkich fotelach pasażerów - miało to miejsce w 1992 r. Z kolei w 2007 r. przewoźnik, jako pierwszy w branży, wprowadził napisy dla niedosłyszących pasażerów. W 2014 r. emiracka linia - również jako pierwsza - rozpoczęła wyświetlanie filmów ze specjalną ścieżkę dźwiękową przeznaczoną dla osób niedowidzących. Od 2013 r. Emirates świadczy usługę oglądania programów telewizyjnych emitowanych na żywo. Jednak bliskowschodniego przewoźnika silnie wyróżnia przede wszystkim stale rozbudowany system rozrywki pokładowej. Na system o nazwie ice składa się 3,5 tys. kanałów w blisko 40 językach (znajdują się w nim również filmy w polskiej wersji językowej oraz utwory muzyczne rodzimych wykonawców). Tym systemem Emirates od kilkunastu lat wygrywa ranking Skytrax, przygotowywany na podstawie opinii milionów pasażerów. Rozrywka dla dzieci ma nie tylko formę bajek oraz gier dostępnych w systemie ice, ale również przedmiotów rozdawanych przez personel pokładowy. Najmłodsze dzieci otrzymują pluszowe zwierzęta z zestawu $F l y$ With Me oraz kolorowanki, z kolei starsze - pakiety Lonely Planet z książeczkami o podróżach.

W uzupełnieniu opisu ofert Singapore Airlines oraz Emirates należy dodać, że nie są to jedyni przewoźnicy, dostarczający wyjątkowych doświadczeń pasażerom. Na podstawie przeglądu ofert innych linii lotniczych można wskazać kolejne, następujące przykłady wdrażania oryginalnych rozwiązań stymulujących zmysły nabywców usług:

- Air Asia - wprowadziły ekskluzywną (dodatkowo płatną) usługę „,zerwonego dywanu" (Red Carpet Service), pozwalającą na szybką obsługą pasażerów od momentu nadania bagażu na lotnisku początkowym po jego odbiór w miejscu docelowym; na usługę składają się m.in. natychmiastowa kontrola bezpieczeństwa, dostęp do wygodnej poczekalni, możliwość wcześniejszego wejścia na pokład, transport do samolotu na wózku elektrycznym;

- Qantas - zaoferowały elektroniczne etykiety na bagaże o nazwie „Q Bag Tag” (w cenie 29,95 AUD); znaczniki bazują na bezprzewodowych rozwiązaniach RFID i zawierają takie informacje, jak: imię i nazwisko właściciela bagażu, jego adres, miejsce wylotu oraz cel podróży; etykiety umożliwiają samoobsługową odprawę i szybkie odnalezienie zagubionego bagażu; 
- Etihad Airways - włączyły do zespołu pokładowego stewardesy-nianie (wyróżniające się strojem), których zadaniem podczas długodystansowych lotów jest asystowanie rodzicom z małymi dziećmi oraz opieka nad samotnie podróżującymi najmłodszymi pasażerami;

- Air France - w Warszawie podróżni, posiadający bilet pierwszej klasy (na wybranych lotach międzykontynentalnych), mają do wyboru transport limuzyną na lotnisko lub nocleg w hotelu Sofitel; ponadto pasażerowie mogą korzystać z linii telefonicznej Premium, dedykowanej klientom ze statusem VIP, w której można uzyskać wszystkie informacje związane z podróżą;

- Finnair oraz KLM - fińskie linie wprowadziły usługę, która umożliwia pasażerom odprawę na swój lot za pośrednictwem popularnego serwisu społecznościowego Facebook, po zakończeniu tej czynności pasażer może udostępnić znajomym w serwisie cel podróży oraz godzinę przylotu do miejsca docelowego; z kolei KLM w przypadku wszystkich podróży do i z Amsterdamu - stworzył możliwość sprawdzania na portalach społecznościowych (Facebook, LinkedIn) profili osób, które podróżują tym samym lotem, dzięki temu można m.in. wybrać miejsce obok osoby o takich samych zainteresowaniach.

Powyższe przykłady pokazują, że można zidentyfikować wiele przejawów dostarczania oryginalnych bodźców pasażerom samolotów. Jednak w przypadku Singapore Airlines oraz Emirates daje się zauważyć, że bodźce te są zintegrowane i nie sprowadzają się tylko do wykorzystywania pojedynczych stymulatorów sensorycznych.

\section{PODSUMOWANIE}

Coraz częściej przy ocenie oferty usług lotniczych przez klientów pojawiają się dwa kluczowe aspekty - cena oraz doświadczenie pasażera ${ }^{27}$. Ze względu na opłacalność biznesów przewoźników, możliwości konkurowania przez nich za pomocą ceny, wyczerpują się. $\mathrm{W}$ związku z tym najszersze perspektywy rysują się w obszarze kojarzenia unikatowych doznań podróżujących osób z markami linii lotniczych.

Dokonanie zmian w systemie zarządzania doświadczeniem klientów stanowi obecnie spore wyzwanie dla przewoźników. Ulepszenie „twardego” komponentu produktu usługowego - samolotów oraz infrastruktury portów lotniczych - jest kosztownym sposobem wyróżnienia się linii, a zwrot z tej inwestycji następuje niekiedy po długim czasie. Z kolei zwiększanie atrakcyjności „miękkiego” elementu produktu - przez przyjemne i bezproblemowe doświadczenia klientów we wszystkich aspektach podróży lotniczej, od momentu rezerwacji do lądowania i na kolejnych etapach - jest tańsze, jednak często trudniejsze do zrealizowania. Zwykle takie usprawnienia wiążą się z całościową zmianą w obszarze kultury organizacyjnej, w tym przede wszystkim w wymiarze postaw i zachowań pracowników pierwszej linii, mających kontakt $\mathrm{z}$ klientami ${ }^{28}$. Ponadto zarządzanie doświadczeniem klientów linii lotniczych stanowi wyzwaniem z innego względu - na podróż pasażera, oprócz lotu, składają się także etapy niezależne od przewoźnika, jak np. transport do portu

${ }^{27}$ D. Rucińska, J. Kotarbiński, Wspótczesne modele komunikacji..., s. 55.

${ }_{28}$ Por. Wzbijajac się ponad chmury. Czy rynek lotniczy utrzyma dynamiczne tempo wzrostu? Badanie PwC Global Airline CEO Survey 2015, s. 10, https://www.pwc.pl/pl/publikacje/2016/wzbijajacsie-ponad-chmury.html (dostęp: 9.05.2018 r.). 
lotniczego, odprawa celna i bagażowa, kontrola bezpieczeństwa na lotnisku, boarding. To są również momenty prawdy wspierające lub obciążające wizerunek marki przewoźnika.

Sam lot stwarza ograniczone możliwości zaskakiwania pasażerów oryginalnymi pomysłami, kreującymi długo pamiętane doświadczenia. Okazuje się jednak, że w ramach już istniejących rozwiązań można poszukiwać źródeł unikatowych bodźców - tak, jak ma to miejsce w przypadku opisanych apartamentów pierwszej klasy. Możliwość podróżowania w prywatnych kabinach jako pierwsze w 2003 r. zaoferowały linie Emirates. W kolejnych latach rozwiązanie to zostało powielone przez kolejnych przewoźników - m.in. przez Singapore Airlines. Apartamenty zaoferowano nawet w skrajnie komfortowej i kosztownej wersji, jak zrobiły to linie Etihad Airways, proponując swoim pasażerom lot w The Residence - trzypokojowej kabinie. Ostatnie działania Emirates pokazują jednak, że za sprawą wystroju odwołującego się do wnętrza luksusowych samochodów, czy wirtualnych okien, można w wykorzystywanych od lat pomysłach, szukać nowych wyróżników marki. Nieco wcześniej linia Singapore Airlines również poszukiwała innowacji i jako pierwsza zaoferowała podwójne łóżka w apartamentach (po połączeniu dwóch sąsiadujących ze sobą kabin).

Przegląd obecnych ofert linii lotniczych, jak również analiza historii rozwiązań wdrożonych przez singapurskiego oraz emirackiego przewoźnika pozwalają wskazać podstawowe determinanty osiągnięcia zamierzonego efektu w postaci osobliwych, wyróżniających markę doświadczeń pasażerów. Do takich determinant należy zaliczyć: (1) planowanie z dużym wyprzedzeniem wdrażanych zmian (związanych przede wszystkim z przystosowaniem samolotów); (2) długookresowe i spójne podkreślanie kluczowych wyróżników marki (jak ma to miejsce m.in. w przypadku Singapore Girl); (3) spojrzenie na dostarczane doznania przez pryzmat całego procesu zarządzania doświadczeniem klienta, obejmującego wszystkie ,,punkty styku”, we wszystkich fazach procesu nabywania i konsumowania usługi.

W uzupełnieniu prowadzonych rozważań należy zwrócić uwagę na to, że za wyjątkowe doświadczenia otrzymywane podczas lotu najczęściej trzeba sporo zapłacić. Wprawdzie część ze zidentyfikowanych rozwiązań odnosi się do klasy ekonomicznej, to jednak większość zmian - wprowadzanych z myślą o osobliwych doznaniach - dotyczy klasy biznes, a zwłaszcza pierwszej klasy. W przypadku tego ostatniego poziomu rezerwacyjnego cena biletu waha się w graniach ok. 60-70 tys. zł i jest nieosiągalna dla zdecydowanej większości pasażerów. Jedną z podstaw gospodarki doświadczeń jest jednak założenie, że ciągle zwiększać się będzie liczba nabywców, którzy będą w stanie i zechcą więcej zapłacić za nowe dla nich doświadczenia, którym towarzyszą przyjemne oraz silne emocje.

W świetle zaprezentowanych uwag wyłania się końcowa konkluzja wskazująca na to, że obecnie na rynku regularnych pasażerskich przewozów lotniczych rozszerza się zjawisko dążenia do wyróżniania ofert przewoźników za sprawą kreowania wyjątkowych doświadczeń pasażerów. Słabnie wymiar konkurowania tylko ceną. Ponadto takie właściwości produktu, jak punktualność, nowoczesna flota, czas obsługi reklamacji, korzyści z udziału w programach lojalnościowych, uległy procesowi komodytyzacji (stały się już oczekiwanym przez pasażerów standardem w ofertach linii lotniczych) i w mniejszym stopniu, niż w przeszłości, decydują o pozycji konkurencyjnej na rynku. 


\section{LITERATURA}

1. Arnould E.J., Price L.L., River Magic: Extraordinary Experience and the Extended Service Encounter, „Journal of Consumer Research” 1993, 20/1.

2. Baron S., Harris K., Services Marketing. Text and Cases, Palgrave Macmillan, New York 2003.

3. Bhattacharjee A., Mogilner C., Happiness from Ordinary and Extraordinary Experiences, „Journal of Consumer Research” 2014, 41/1.

4. Boguszewicz-Kreft M., Marketing doświadczeń. Jak poruszać zmysty, zaangażować emocje, zdobyć lojalność klientów?, CeDeWu, Warszawa 2013.

5. Carù A., Cova B., Revisiting Consumption Experience: A More Humble but Complete View of the Concept, „Marketing Theory” 2003, 3/2.

6. Cooney G., Gilbert D.T., Wilson T.D., The Unforeseen Costs of Extraordinary Experience, „Psychological Science” 2014, 25/12.

7. Gamble P.R., Tapp A., Marsella A., Stone M., Marketing Revolution: The Radical New Ap-proach to Transforming the Business, the Brand, and the Bottom Line, Kogan Page, London-Sterling 2007.

8. Kacprzak A., Dziewanowska K., Skorek M., Gospodarka doświadczeń. Perspektywa polskiego konsumenta, Wydawnictwo Naukowe PWN, Warszawa 2016.

9. Kotler Ph., Marketing Insights from A to Z, John Wiley \& Sons, Hoboken 2003.

10. Laming C., Mason K., Customer experience - an analysis of the concept and its performance in airline brands, „Research in Transportation Business \& Management” 2014, 10.

11. Le Bel J.L., Beyond the friendly skies: an integrative framework for managing the air travel experience, ,Managing Service Quality: An International Journal” 2005, 15/5.

12. Pine B.J., Gilmore J.H., Welcome to the Experience Economy, ,Harvard Business Review” 1998, 76/4.

13. Polkowska M., Komunikacja lotnicza na świecie w XXI wieku, „Modern Management Review” XX, 22 (2/2015).

14. Riivits-Arkonsuo I., Leppiman A., Consumer Journey from First Experience to Brand Evangelism, ,Research in Economics and Business: Central and Eastern Europe” 2014, 6/1.

15. Rizvi R.Z., Analysis of the dimensions of customer experience with reference to Indigo Airlines and Jest Airways, „Business Sciences International Research Journal” 2016, 4.

16. Rucińska D., Kotarbiński J., Wspótczesne modele komunikacji marketingowej przewoźników lotniczych [w:] Europejski transport i rynek ustug transportowych, red. D. Rucińska, Zeszyty Naukowe Uniwersytetu Gdańskiego, „Ekonomika Transportu i Logistyka” 2014, 52.

17. Shaw S., Airline Marketing and Management, Ashgate, Aldershot 2007.

18. Skowronek I., Marketing sensoryczny a wartość dla klienta [w:] Zarzadzanie przedsiębiorstwem w pracach doktorantów, red. B. Dobiegała-Korona, Szkoła Główna Handlowa w Warszawie, Warszawa 2009.

\section{NETOGRAFIA}

1. Continued passenger traffic growth and robust air cargo demand in 2017, https://www. icao.int/Newsroom/Pages/Continued-passenger-traffic-growth-and-robust-air-cargodemand-in-2017.aspx (dostęp: 7.05.2018 r.). 
2. Liczba obstużonych pasażerów oraz wykonanych operacji $w$ ruchu krajowym - regularnym $i$ czarterowym $w$ latach 2015-2017, http://www.ulc.gov.pl/_download/statystyki/2017/ wg_portow_krajowe_4kw2017.pdf (dostęp: 7.05.2018 r.).

3. Pogorzelski J., Momenty prawdy i punkty kontaktu, http://jacekpogorzelski.pl/momentyprawdy-i-punkty-kontaktu (dostęp: 10.05.2018 r.).

4. Projekcja liczby obsłużonych pasażerów oraz liczby operacji pasażerskich $w$ Polsce do roku 2035, http://www.ulc.gov.pl/_download/regulacja_rynku/statystyki/prognozy/prognoza_ 2017.pdf (dostęp: 7.05.2018 r.).

5. Wzbijajac się ponad chmury. Czy rynek lotniczy utrzyma dynamiczne tempo wzrostu? Badanie PwC Global Airline CEO Survey 2015, https://www.pwc.pl/pl/publikacje/2016/wzbijajac-sie-ponad-chmury.html (dostęp: 9.05.2018 r.)

\section{EXTRAORDINARY EXPERIENCES OF PASSENGERS AS A DISTINCTIVE FEATURE OF AIRLINES}

In the era of experience economy, the emergence of which was announced at the end of the $20^{\text {th }}$ century, brand competition is observed mainly in the dimension of providing unique experiences. For contemporary customers their extraordinary experiences that accompany purchases and product consumption are becoming more and more often a key determinant of market choices. The literature of the marketing presents experiential marketing in the context of multiple areas of economic activity - inter alia, tourism, retailing, banking services. There are, however, no publications (in particular, when one considers the Polish literature) on experiences created while using services of airlines. This paper aims to set out reasons for extending a carriers' offer by including customers' extraordinary experiences in the context of the uniqueness of the passenger air transport industry. The author's intention was also to identify the signs of carriers' actions aimed at creating exceptional, long-lasting experiences. For the purpose of the text, a category of "customer's extraordinary experience" was put forward. Conclusions presented herein were drawn on the basis of literature review and the author's own experience, who has used services provided by more than twenty airlines. Exemplification to support the discussions herein is based on two carriers, both regarded as the product innovation leaders - Singapore Airlines and Emirates. Solutions introduced by them served as a basis for conclusions concerning the importance of unique experiences compared to other offer components based on which airlines compete on the passenger air transport market. Further, determinants of effective introduction of new solutions designed to create extraordinary experiences were presented. Such determinants include, inter alia, the planning of changes to be introduced well in advance, emphasizing key brand values in a coherent way - by multiple stimuli and in a long-term perspective; consideration of provided experiences from the angle of the entire customer experience management process.

Keywords: experiential marketing, extraordinary customer experience, customer experience management, airline marketing.

DOI: $10.7862 / \mathrm{rz} .2018 . \mathrm{mmr} .26$

Tekst złożono do redakcji: czerwiec $2018 \mathrm{r}$.

Tekst przyjęto do druku: wrzesień 2018 r. 
